\title{
Pemanfaatan Teknologi Audio Visual dengan Metode Resitasi pada Mata Pelajaran Pkn dalam Mengoptimalkan Prestasi Belajar Siswa di MTs Thoriqulhuda Dano
}

\author{
Jaja Jamaludin" ${ }^{\# 1}$, Uun Hasanah ${ }^{\# 2}$, Omin ${ }^{\# 3}$ \\ \#Program Studi Teknologi Pendidikan, Pascasarjana Institut Pendidikan Indonesia Garut \\ Jl. Terusan Pahlawan No.32, Sukagalih, Kec. Tarogong Kidul, Kabupaten Garut Email : \\ ${ }^{j}$ jaja jamaludin mhseinstitutpendidikan.ac.id \\ uunhasanah94@gmail.com \\ 3ominerminegmail.com
}

\begin{abstract}
This research is done in an effort to find out the use of audio visual technology using recitation method on Civics Subject in optimizing students' learning achievement, the research's design is Quasi experiment using two groups. In group learning the experiment uses audio visual aid using recitation method while control class is using recitation method without audio visual aid. Test is used to obtain research to find out aspect of remembering and aspect of understanding in the form of multiple choices. Based on findings result and study it was obtained the conclusion of learning result of students who acquired better learning using recitation and audio visual aid than those of who without audio visual aid it can be seen from experiment class' average score is 11,94 and control class is 10.41.
\end{abstract}

Key words: Audio Visual Technology, Recitation Media, Civics Subject

Abstrak - Penelitian ini dilakukan dalam upaya untuk mengetahui pemanfaatan teknologi audio visual dengan metode resitasi pada mata pelajaran PKn dalam mengoptimalkan hasil belajar siswa, desain penelitiannya adalah eksperimen semu dengan menggunakan dua kelompok. Dalam pembelajaran kelompok eksperimen menggunakan alat bantu audio visual dengan metode resitasi sedangkan kelas kontrol menggunakan metode resitasi tanpa bantuan audio visual. Tes digunakan untuk memperoleh penelitian untuk mengetahui aspek mengingat dan aspek pemahaman berupa pilihan ganda. Berdasarkan hasil temuan dan pembelajaran diperoleh kesimpulan hasil belajar siswa yang memperoleh pembelajaran lebih baik dengan menggunakan alat bantu resitasi dan audio visual dibandingkan dengan siswa yang tidak menggunakan alat bantu audio visual terlihat dari nilai rata-rata kelas eksperimen adalah 11,94 dan kontrol. kelasnya adalah 10.41 .

Kata Kunci : Teknologi Audio Visual, Media Resitasi, Mata Pelajaran PKn

\section{PENDAhULUAN}

Perkembangan ilmu pengetahuan dan teknologi yang semakin mendorong upaya pembaharuan dalam pemanfaatan hasil teknologi dalam proses belajar mengajar. Hal tersebut dibuktikan dengan pemanfaatan teknologi sebagai salah satu media pembelajaran di sekolah. Media pembelajaran diharapkan mampu memberikan motivasi dan merangsang aktivitas siswa dalam belajar.

Pembelajaran dengan menggunakan media akan membangkitkan motivasi belajar yang lebih baik daripada tanpa media. Guru sebagai pendidik profesional harus mampu berperan sebagai komunikator dan fasilitator bagi siswa di kelasnya. Sebagai komunikator, seorang guru harus mampu menyampaikan pesan pembelajaran kepada siswanya bahwa mereka berperan sebagai komunikator, mengkomunikasikan materi pembelajaran dalam bentuk verbal dan non verbal [1], [2].

Pembelajaran pada materi ini memiliki tingkat kesulitan dan kepadatan yang tinggi. Hal ini disebabkan banyaknya konsep ruang lingkup yang harus dikuasai dalam materi tersebut sehingga akan menimbulkan berbagai masalah bagi guru saat menyampaikannya [2].

Salah satu upaya yang dilakukan oleh guru dalam menghadapi kondisi pembelajaran tersebut diatas maka dapat dipilih metode pembelajaran yang efektif dan dapat dilakukan dengan mudah. Salah satunya adalah penggunaan metode resitasi yang dapat dijadikan salah satu alternatif, terutama dalam menuangkan materi ide dari beberapa artikel dan buku melalui kegiatan membaca [2].

Berbicara tentang mewujudkan suasana pembelajaran, tidak dapat dilepaskan dari upaya menciptakan lingkungan belajar, diantaranya mencakup: (a) lingkungan fisik, seperti: 
bangunan sekolah, ruang kelas, ruang perpustakaan, ruang kepala sekolah, ruang guru, ruang Bimbingan Konseling, taman sekolah dan lingkungan fisik lainnya; dan (b), lingkungan sosio-psikologis (iklim dan budaya belajar/akademik), seperti: komitmen kerja sama, kreativitas, toleransi, kenyamanan, kebahagiaan dan aspek-aspek sosio-

konteks pembelajaran yang dilakukan guru, tampak jelas bahwa keterampilan guru dalam mengelola kelas (classroom managemet) menjadi amat penting serta peran guru lebih diutamakan sebagai fasilitator belajar peserta didik.

Media pembelajaran digunakan dalam rangka komunikasi dan interaksi antara guru dan siswa dalam proses pembelajaran. Metode pembelajaran berbasis teknologi dan komunikasi didasarkan pada kemampuan guru dalam mengolah berbagai sumber informasi yang tersedia dan berkembang secara signifikan, antara lain pemanfaatan komputer (internet), pembelajaran VCD, televisi dan radio. Media sebagai alat bantu memiliki fungsi untuk memudahkan pencapaian tujuan pembelajaran. Hal ini didasari oleh keyakinan bahwa proses pembelajaran dengan bantuan media dapat meningkatkan aktivitas belajar siswa dalam kurun waktu yang cukup lama.

Mata pelajaran PKn merupakan salah satu mata pelajaran di semua jenjang pendidikan. Mulai dari SD sampai SMA kita bisa temukan Pelajaran PKn. Bahkan di tingkat perguruan tinggi kita masih bisa menemukan PKn. Menurut Peraturan Menteri Pendidikan Nasional Republik Indonesia nomor 24 tahun 2006 pasal 37 disebutkan bahwa Pendidikan PKn merupakan mata pelajaran yang harus diajarkan dalam kurikulum pendidikan Indonesia karena Pendidikan PKn difokuskan pada pembentukan warga negara yang memahami dan mampu menjalankan hak dan kewajibannya. Menjadi warga negara yang cerdas, terampil, dan berkarakter berdasarkan Pancasila dan UUD 1945.

Terkait dengan proses pembelajaran, maka diperlukan suatu media pembelajaran yang mampu menggambarkan konsep PKn secara nyata. Penggunaan media dalam proses pembelajaran diharapkan dapat membantu kelancaran proses pembelajaran [3].

Media pembelajaran memiliki pengaruh positif dalam proses belajar mengajar karena media tersebut disebut sebagai alat bagi guru untuk mentransfer materi pembelajaran kepada siswa. Dengan adanya media pembelajaran dapat mengatasi keterbatasan pengalaman siswa, seperti ketersediaan buku, kesempatan membaca dan sebagainya. Jika siswa dapat ditempatkan pada suatu benda secara langsung, maka benda tersebut dibawa kepada siswa [4]. Dilihat dari perkembangan media, audio visual dapat dikatakan paling efektif dalam menyampaikan pesan kepada khalayak dibandingkan media lainnya. Salah satu media yang dapat digunakan adalah video. Video merupakan media audio visual yang mampu mengungkap objek dan peristiwa seperti kenyataannya. Dengan menggunakan video siswa dapat memahami pesan pembelajaran secara lebih bermakna sehingga informasi yang disampaikan melalui video dapat dipahami dengan mudah [5]. emosional lainnya yang memungkinkan peserta didik untuk melakukan kegiatan belajar. Baik lingkungan fisik maupun lingkungan sosi-psikologis, keduanya didesain agar peserta didik dapat secara aktif mengembangkan segenap potensinya. Dalam

Menurut Marshall McLuhan definisi media adalah keberadaan manusia yang memungkinkan untuk mempengaruhi orang lain tanpa harus bersentuhan langsung. Media audio visual berasal dari kata media yang berarti bentuk perantara yang digunakan manusia untuk menyampaikan atau menyebarkan gagasan atau pendapat sehingga dapat disampaikan kepada khalayak yang diinginkan. Dale mengatakan media Audio Visual merupakan media pembelajaran yang mengaktifkan mata dan telinga siswa pada saat proses belajar mengajar berlangsung. Media Audio Visual merupakan media yang tidak hanya berisi suara tetapi juga berisi gambar-gambar yang dapat dilihat, seperti rekaman video, berbagai ukuran film, slide suara dan lain sebagainya. Kemampuan media ini dinilai semakin baik dan menarik karena mengandung dua unsur tersebut [6].

\section{Tinjauan Pustaka}

\section{A. Pembelajaran kooperatif}

Pembelajaran adalah pendekatan yang berorientasi pada kerjasama antar peserta didik dalam bentuk kelompok sehingga peserta didik dapat belajar bersama dalam suasana kelompok. Pembelajaran kooperatif berasal dari kooperatif yang artinya mengerjakan sesuatu secara bersama-sama dengan saling membantu satu sama lainnya sebagai satu kelompok atau satu tim.

Slavin (dalam Sanjaya, 2010: 244) mengemukakan: "pembelajaran kooperatif adalah suatu model pembelajaran dimana kelompok belajar bekerja dalam kelompok-

kelompok kecil yang berjumlah empat orang secara kolaboratif sehingga dapat merangsang siswa lebih bergairah dalam belajar'.

Sedangkan Johnson dan Johnson (dalam Warsono dan Hariyanto,2012:166) mengemukakan bahwa pembelajaran kooperatif adalah suatu pengajaran yang melibatkan peserta didik untuk bekerja sama dalam tim, menyelesaikan suatu tujuan pembelajaran, dalam suatu kondisi yang meliputi sejumlah unsur berikut:

1. Saling ketergantungan positif, yaitu anggota tim terikat untuk bekerja sama satu sama lain dalam mencapai tujuan pembelajaran, Jika ada anggota tim yang gagal mengerjakan bagiannya, setiap orang anggota tim lainnya akan memperoleh konsekuensi ( berenang atau tenggelam bersama, swim or sink together):

2. Tanggung jawab individu, yaitu seluruh peserta didik dalam tim bertanggung jawab untuk mengerjakan bagian tugasnya sendiri serta wajib menguasai materi pembelajaran;

3. Interaksi tatap muka, walaupun setiap anggota tim secara perorangan mengerjakan tugas bagiannya sendiri, 
sejumlah tugas harus dikerjakan secara interaktif, masingmasing memberikan masukan, penalaran dan kesimpulan, dan lebih penting lagi mereka saling mengajari dan memberikan dorongan satu sama lain;

4. Penerapan keterampilan kolaboratif, di mana peserta didik didorong dan dibantu untuk mengembangkan rasa saling percaya, kepemimpinan, pengambilan keputusan, komunikasi dan keterampilan mengelola konflik.

5. Proses kelompok, dimana anggota tim menetapkan tujuan kelompok, secara periodik menilai hal-hal yang tercapai dengan baik dalam tim, serta mengidentifikasi perubahan yang harus dilakukan agar ke depan tim dapat berfungsi lebih efektif.

\section{B. Pengertian Pembelajaran}

Pengertian pembelajaran adalah suatu proses yang dilakukan oleh individu untuk memperoleh suatu perubahan prilaku yang baru secara keseluruhan, sebagai hasil dari pengalaman individu itu sendiri dalam interaksi dengan lingkungannya (Surya,2004:7).

Pembelajaran merupakan suatu proses yang sistematis yang mengisyaratkan adanya orang yang mengajar dan belajar dengan didukung oleh komponen lainnya, seperti kurikulum, fasilitas belajar mengajar. Dalam proses tersebut terdapat kegiatan memilih, menetapkan dan mengembangkan metode atau pendekatan untuk mencapai hasil pembelajaran yang diinginkan. Hamalik $(2011,57)$ mengemukakan:

"Pembelajaran adalah suatu kombinasi yang tersusun meliputi unsur-unsur manusiawi, material, fasilitas, perlengkapan, dan prosedur yang saling me mpengaruhi mencapai tujuan pembelajaran. Manusia terlibat dalam sistem pengajaran terdiri dari siswa, guru, dan tenaga lainnya, misalnya tenaga laboratorium. Material, meliputi: bukubuku, papan tulis, dan kapur, audio. Fasilitas dan perlengkapan, terdiri dari ruangan kelas. Prosedur meliputi: jadwal dan metode penyampaian informasi,praktik, belajar ujian dan sebagainya".

Pembelajaran merupakan suatu sistem, yang terdiri atas berbagai komponen yang saling berhubungan satu dengan yang lainnya. Komponen tersebut meliputi: tujuan , materi, metode, dan evaluasi (Rusman,2011:1).

Berdasarkan ketiga pendapat diatas bahwa pembelajaran adalah usaha sadar dari seorang pengajar untuk membuat peserta didik belajar dengan suatu kombinasi yang terdiri dari berbagai unsur diantaranya: ada pembelajar dan pengajar dengan fasilitas perlengkapan ruang kelas dan yang lainnya yang saling berhubungan dan saling mempengaruhi satu sama lain dinataranya : tujuan, materi, metode sehingga memperoleh suatu perubahan prilaku yang baru secara keseluruhan dari hasil pengalaman belajar, pembelajaran merupakan suatu kegiatan yang dilakukan secara sistematis yang diawali dengan persiapan mengajar (prainstruksional), proses pembelajaran (instruksional), dan diakhiri penilaian atau evaluasi. Kunci pokok pembelajaran ada pada guru (pengajar), tetapi bukan berarti hanya guru yang aktif sedang peserta didik pasif. Pembelajaran menuntut kedua belah pihak yang sama-sama menjadi subjek pembelajaran agar proses pembelajaran dapat berlangsung secara optimal dalam mencapai tujuan pembelajaran. Menurut (Hamalik,2011:66): bahwa unsur-unsur minimal yang, harus ada dalam sistem pembelajaran adalah seorang peserta didik, suatu tujuan dan suatu prosedur kerja untuk mencapai tujuan. Dalam hal ini guru (pengajar) tidak termasuk sebagai unsur sistem pembelajaran fungsinya dapat digantikan atau dialihkan kepada media sebagai pengganti, seperti : buku, slide, teks yang diprogram, dan sebagainnya. Namun seorang kepala sekolah dapat menjadi salah satu unsur pembelajaran, karena berkaitan dengan prosedur perencanaan dan pelaksanaan pembelajaran.

Aplikasi teori pembelajaran dalam kegiatan pembelajaran ini berkaitan dengan: (a) bagaimana cara yang efektif untuk mentrasfer ilmu; (b) prinsip-prinsip pembelajaran yang menggairahkan;menantang dan menyenangkan; (c) cara membangun minat dan perhatian (attention) peserta didik; (d) cara mengembangkan relevansi (relevance) dalam pembelajaran; (e) cara membangkitkan percaya diri (confidence) peserta didik dalam pembelajaran; (f) cara meningkatkan kepuasan (satisfaction) peserta didik dalam pembelajaran; dan (g) cara membuat laporan tentang analisis kebutuhan untuk pembelajaran. (warsita, 2008: 87).

Perkembangan teori pembelajaran, ada tiga teori dalam kegiatan pembelajaran, yaitu : behaviorisme,kognitivisme, dan kontruktivisme. Beberapa tokoh penting pada perkembangan teori behaviorisme ialah Pavlov (1849-1936), thorndike (1874-1949), Watson (1878-1958), dan Skiner (1904-1990).

a. Prinsip-prinsip dasar pembelajaran menurut teori behaviorisme adalah:

1. Menekankan pada pengaruh lingkungan terhadap perubahan perilaku;

2. Menggunakan prinsip penguatan, yaitu untuk mengidentifikasi aspek paling diperlukan dalam pembelajaran dan untuk mengarahkan kondisi agar peserta didik dapat mencapai penigkatan yang diharapkan dalam tujuan pembelajaran;

3. Mengidentifikasi karakteristik peserta didik, untuk menentapkan tujuan pembelajaran; dan

4. Lebih menekankan pada hasil belajar dari pada proses pembelajaran.

b. Prinsip-prinsip dasar pembelajaran menurut teori kognitivisme adalah :

1. Pembelajaran merupakan suatu perubahan status pengetahuan;

2. Peserta didik merupakan peserta aktif di dalam proses pembelajaran;

3. Menekankan pada pembentukan pola pikir peserta didik;

4. Berpusat pada cara peserta didik mengingat, memperoleh kembali dan menyimpan informasi dalam ingatannya; 
5. Menenkankan pada pengalaman belajar,dengan memandang pembelajaran sebagai proses aktif di dalam diri peserta didik;

6. Menerapkan reward and punishment;

7. Hasil pembelajaran tidak hanya tergantung pada informasi yang disimpulkan guru, tetapi juga pada cara peserta didik memproses infomasi tersebut.

c. Prinsip-prinsip dasar pembelajaran menurut teori kontruktivisme adalah ;

1. Membangun inpretasi peserta didik berdasarkan pengalaman belajar;

2. Menjadikan pembelajaran sebagai proses aktif dalam membangun pengetahuan tidak hanya sebagai proses komunikasi penegtahua;

3. Kegiatan pembelajaran bertujuan untuk pemecahan masalah (problem solving);

4. Pembelajaran bertujuan pada proses pembelajaran itu sendiri, bukan pada hasil pembelajaran;

5. Pembelajaran berpusat pada peserta didik;

6. Mendorong peserta didik dalam mencapai tingkat berpikir yang lebih tinggi (high order thingking).

Dari penjelasan di atas, dapat disimpulkan bahwa pembelajaran menurut teori Behaviorisme menekankan pada hasil belajar dari pada proses pembelajaran peserta didik dan lingkungan sangat berpengaruh terhadap perubahan perilaku dan mengarahkan kondisi agar peserta didik dapat mencapai penigkatan yang diharapkan dalam tujuan pembelajaran. Teori pembelajaran Kognitivisme menekankan pada proses pembelajaran peserta didik yang harus aktif dari pengalaman belajar, sedangkan teori pembelajaran Kontruktivisme pembelajaran sebagai proses aktif dalam membangun pengetahuan tidak hanya sebagai proses komunikasi pengetahuan serta mendorong peserta didik dalam mencapai tingkat berpikir yang lebih tinggi.

\section{Implikasi Kontruktivisme dalam Pembelajaran}

Belajar berarti membentuk makna. Makna dalam hal ini merupakan hasil bentukan siswa sendiri yang bersumber dari apa yang mereka lihat, rasakan, dan alami. Kontruksi dalam artian terkait dengan pengertian yang telah ia miliki.

Kontrusksi berarti merupakan suatu proses yang berlangsung secara dinamis. Setiap seseorang berhadapan dengan fenomena atau pengalaman-pengalaman baru, siswa melakukan rekontruksi.

Secara substansial, belajar bukanlah aktivitas penghimpunan fakta atau informasi, akan tetapi lebih kepada upaya pengembangan pemikiran-pemikiran baru. Belajar bukan merupakan hasil perkembanagn akan tetapi merupakan perkembangan itu sendiri Fosnot (dalam Aunurrahman,2012;19),suatu perkembangan yang menuntut penemuan dan pengaturan kembali pemikiran-pemikiran seseorang.

Proses belajar yang sebenarnya terjadi ketika skema pemikiran seseorang dalam keraguan menstimulir pemikiran-pemikiran lebih lanjut. Dalam waktu-waktu tertentu situasi mengandung keragu-raguan memiliki unsur positif untuk mendorong siswa belajar.

Hasil belajar dipengaruhi oleh pengalaman siswa tentang lingkungannya

Hasil belajar siswa tergantung dari apayang telah ia ketahui, baik berkenaan dengan pengertian, konsep, formula dan sebagainya. Prinsip-prinsip belajar menurut Surya (2004:8) yaitu :

1. Pembelajaran sebagai usaha memperoleh perubahan perilaku. Prinsip ini mengandung makna bahwa ciri utama proses pembelajaran ialah adanya perubahan perilaku dalam diri individu. Artinya seseorang yang telah mengalami pembelajaran akan berubah perilakunya, tetapi tidak semua perubahan perilaku sebagai hasil pembelajaran. Perubahan perilaku hasil pembelajaran mempunyai ciri-ciri sebagai berikut :

1) Perubahan yang disadari, artinya individu yang melakukan proses pembelajaran menyadari bahwa pengetahuannya telah bertambah.

2) Perubahan yang bersifat kontinu ( berkesinambungan). Perubahan perilaku sebagai hasil pembelajaran akan berlangsung secara berkesinambungan, artinya suatu perubahan yang telah terjadi, menyebabkan terjadinya perubahan perilaku yang lain.

3) Perubahan yang bersifat fungsional, artinya perubahan yang telah diperoleh sebagai hasil pembelajaran memberikan manfaat bagi individu yang bersangkutan.

4) Perubahan yang bersifat positif, artinya terjadi adanya pertambahan perubahan dalam diri individu. Perubahan yang diperoleh senantiasa bertambah sehingga berbeda dengan keadaan sebelumnya.

5) Perubahan yang bersifat aktif, artinya perubahan tidak terjadi dengan sendirinya, akan tetapi melalui aktivitas individu.

6) Perubahan yang bersifat permanen (menetap), artinya perubahan terjadi sebagai hasil pembelajaran akan berada secara kekal dalam diri individu, setidaktidaknya untuk masa tertentu.

7) Perubahan yang bertujuan dan terarah, artinya perubahan itu terjadi karena ada sesuatu yang akan dicapai.

2. Hasil pembelajaran ditandai dengan perubahan perilaku secara keseluruhan.

3. Pembelajaran merupakan suatu proses.

4. Proses pembelajaran terjadi karena adanya sesuatu tujuan yang akan dicapai.

5. Pembelajaran merupakan bentuk pengalaman.

Perubahan dan perilaku yang terjadi mengalami suatu pengalaman dan proses pada dasarnya adalah pembelajaran yang nyata dalam kehidupan sehari-hari, sehingga tercipta suatu situasi yang menyenangkan dan mendapat suatu pengalaman yang positif atau yang sangat berarti

Prinsip-prinsip belajar dalam aplikasinya di dalam proses belajar mengajar, pendidik dapat melaksanakan tugasnya 
dengan baik apabila dapat menerapkan cara mengajar sesuai dengan prinsip-prinsip belajar, dalam pembelajaran yaitu landasan berpikir, landasan berpijak dan sumber motivasi dengan harapan dan tujuan pembelajaran tercapai dan tumbuhnya proses belajar antara peserta didik dan pendidik yang dinamis dan terarah.

Pembelajaran dapat dimaknai sebagai aktivitas atau kegiatan yang berfokus pada kondisi dan kepentingan pembelajar (learner centered). Istilah pembelajaran digunakan untuk mengganti istilah "pengajaran" (teaching) yang lebih bersifat sebagai aktivitas yang berfokus pada guru (teacher centered). Kegiatan pengajaran perlu dibedakan dari kegiatan pembelajaran (Miarso,2005:144). Pengajaran merupakan istilah yang diartikan sebagai penyajian bahan ajar yang dilakukan oleh pengajar, sedangkan pembelajaran tidak harus diberikan oleh seorang pengajar, karena kegiatan ini dapat dilakukan oleh perancang dan pengembang sumber belajar, misalnya seorang teknolog pembelajar atau suatu tim ahli tertentu. Proses pembelajaran dialami sepanjang hayat seorang manusia serta dapat berlaku di manapun dan kapanpun. Pembelajaran yaitu suatu proses untuk membantu peserta didik agar dapat belajar dengan baik.

\section{Jenis Media Audio Visual}

Jenis Media Audio Visual adalah sebagai berikut:

\section{Audio-Visual Murni}

Audio Visual Murni atau lebih sering disebut audio visual gerak adalah suatu media yang dapat menampilkan elemen suara dan gambar bergerak, elemen suara atau gambar tersebut berasal dari suatu sumber.

\section{Film Suara}

Film atau gambar bergerak adalah gambar dalam bingkai di mana bingkai demi bingkai diproyeksikan melalui lensa proyektor secara mekanis sehingga gambar yang terlihat hidup di layar. Film merupakan alat yang ampuh untuk menyampaikan ide kepada penonton dan anak-anak yang menggunakan aspek emosional lebih banyak dibandingkan dengan aspek rasionalitasnya. Besarnya penggunaan media juga dapat dirasakan dalam dunia bisnis, dalam hal ini menarik perhatian konsumen. Film bersuara sangat banyak jenisnya, untuk tujuan hiburan seperti bioskop atau film, namun film bersuara dalam istilah ini adalah siaran sepak bola yang dapat menarik minat konsumen untuk datang [7].

\section{Video}

Video sebagai media audio visual yang menampilkan gerakan semakin hari semakin populer. Pesan yang disampaikan bersifat faktual atau fiksi, bisa informatif, edukatif atau instruksional. Sebagian besar tujuan film dapat digantikan oleh video, tetapi bukan berarti video akan menggantikan film itu sendiri. Media video merupakan salah satu bentuk media audio visual selain film yang banyak dikembangkan untuk keperluan pembelajaran [8].

\section{Televisi}

Televisi dalam maknanya berasal dari dua kata yaitu tele (yunani) yang artinya jauh dan visi (latin) yang artinya penglihatan. Televisi berarti penglihatan yang jauh. Kata penglihatan jauh mengandung makna bahwa gambar yang dihasilkan di suatu tempat dapat dilihat dari tempat yang jauh dengan menggunakan alat penerima yang disebut monitor televisi atau televisi. Televisi merupakan suatu peralatan elektronik yang pada dasarnya sama dengan gambar hidup atau radio yang dapat menampilkan gambar yang dapat dilihat dan menghasilkan suara yang dapat didengar pada waktu yang bersamaan.

\section{Audio Visual TIDAK MURNI}

Audio Visual yang tidak murni adalah suatu elemen media yang elemen suara dan gambarnya berasal dari berbagai sumber. Audio visual tidak murni sering juga disebut dengan audio visual plus suara yaitu media yang menampilkan suara dan gambar diam seperti itu.

Slide suara (sound film frame) slide atau strip film yang ditambah dengan suara bukanlah audio visual yang lengkap, karena suara dan gambar terpisah, oleh karena itu slide atau filmstrip hanyalah media audio visual atau masih visual ditambah suara. Kombinasi slide dan pita audio adalah sistem multimedia yang paling mudah diproduksi.

Kombinasi slide tape dari slide dan tape dapat digunakan di lokasi yang berbeda dan untuk berbagai tujuan pembelajaran dan meningkatkan upaya yang menyertakan gambar untuk menginformasikan atau mendorong respon emosional. Sounded slide merupakan salah satu inovasi yang dapat digunakan sebagai media dalam berbisnis maupun dalam pembelajaran.

Permasalahan lain yang terkait dengan permasalahan pendidikan kewarganegaraan selama ini adalah persepsi siswa terhadap cara guru mengajar. Berdasarkan pendapat siswa atas observasi peneliti yang dilakukan terhadap guru mata pelajaran PKn saat mengajar hanya mengulang cerita, membosankan dan menjengkelkan. Berkaitan dengan permasalahan tersebut penulis mencoba menggunakan media audio visual berupa video sebagai alat komunikasi antara siswa dan guru dalam menerima pesan pembelajaran [9].

Berdasarkan latar belakang tersebut di atas, maka dilakukan penelitian, "Pemanfaatan Teknologi Audio Visual Menggunakan Metode Resitasi pada Mata Pelajaran PKn di MTs Thoriqulhuda, Dano”.

\section{Metode Penelitian}

Berdasarkan hasil observasi yang dilakukan di MTs Thoriqulhuda, Dano, peneliti bermaksud untuk meneliti hasil belajar siswa kelas VII. Hasil belajar siswa semakin rendah karena kurang berminat pada mata pelajaran khususnya PKn. Rendahnya hasil belajar siswa khususnya mata pelajaran PKn perlu segera diatasi. Pemilihan siswa kelas VII MTs Thoriqulhuda Dano sebagai subjek penelitian didasarkan pada hasil wawancara peneliti dengan guru PKn.

Metode ini merupakan validasi atau pengujian yaitu menguji pengaruh satu atau lebih variabel terhadap variabel lainnya. Variabel yang memberikan pengaruh dikategorikan sebagai variabel bebas, dan variabel yang berpengaruh 
dikategorikan sebagai variabel terikat, karena penelitian ini adalah pengujian, maka semua variabel yang diuji harus diukur dengan menggunakan alat ukur atau uji standar.

Bentuk eksperimen yang digunakan adalah eksperimen semu. Rancangan ini memiliki kelas kontrol, namun tidak dapat berfungsi sepenuhnya untuk mengontrol variabel luar yang mempengaruhi pelaksanaan eksperimen, atau suatu bentuk eksperimen yang sifat validasinya utamanya tidak melakukan penugasan acak tetapi menggunakan kelompok yang ada, dalam hal ini kelas normal. Dengan menggunakan kelompok kontrol sebagai dasar untuk dibandingkan dengan kelompok eksperimen yang diberikan perlakuan. Desain penelitian dijelaskan pada tabel berikut:

TABEL I.

Desain Penelitian.

\begin{tabular}{|l|l|l|l|}
\hline Class & Initial test & Treatment & Final test \\
\hline Experiment & $\mathrm{O}$ & $\mathrm{X}_{1}$ & $\mathrm{O}$ \\
\hline Control & $\mathrm{O}$ & $\mathrm{X}_{2}$ & $\mathrm{O}$ \\
\hline
\end{tabular}

Informasi:

$\mathrm{X}_{1}=$ kelas dengan model pembelajaran resitasi audio visual $\mathrm{X}_{2}=$ kelas dengan model pembelajaran resitasi audio visual

Sampel adalah bagian dari jumlah atau karakteristik yang dimiliki oleh populasi itu sendiri. Sampel digunakan jika populasinya besar dan tidak memungkinkan bagi peneliti untuk mempelajari segala sesuatu yang ada dalam populasi tersebut, oleh karena itu peneliti dapat menggunakan sampel yang diambil dari populasi tersebut.

Pengambilan sampel merupakan proses pemilihan dan penentuan jenis sampel serta perhitungan besarnya sampel yang akan dijadikan subjek atau objek penelitian. Sampel yang akan diteliti secara nyata harus representatif dalam arti mewakili populasi baik dalam jumlah maupun karakter. Adapun pengambilan sampelnya bersifat random artinya setiap individu dalam populasi memiliki peluang yang sama untuk dijadikan sampel.

\section{HASIL DAN PEMBAHASAN}

Dalam kelompok ini siswa harus aktif dalam proses pembelajaran karena akan memperoleh pengalaman langsung sebagai subjek pembelajaran dan proses diskusi kelompok sebagai objeknya, terlebih lagi pada materi subjek sebagai objek penelitian banyak yang harus diketahui oleh siswa tentang materi segitiga. Interaksi ini akan memberikan kontribusi yang positif dalam proses pembelajaran sehingga diharapkan dapat meningkatkan pengetahuan siswa.

Sebelumnya peneliti memberikan tes kepada kedua kelas (kelas kontrol dan eksperimen). Tahap selanjutnya dalam tes instrumen dilakukan uji coba instrumen penelitian yang meliputi validitas, reliabilitas, daya pembeda dan tingkat kesukaran soal yang diujikan. Menurut Suherman dan Sukjaya (1990: 134), "bahwa untuk memperoleh alat evaluasi yang mutunya baik perlu memperhatikan beberapa kriteria yang harus dipenuhi”. Kriteria yang dimaksud adalah nilai validitas, reliabilitas pertanyaan yang sesuai dengan standar evaluasi. Dari hasil analisis terlihat bahwa pertanyaan tersebut memenuhi kriteria alat evaluasi yang baik [10].

Setelah dilakukan analisis terhadap soal-soal, kemudian soal-soal tersebut dibagikan kepada siswa dalam bentuk pretest dan post-test. Pre-test bertujuan untuk mengukur kemampuan siswa sebelum pembelajaran dilaksanakan, sedangkan post-test bertujuan untuk mengetahui hasil belajar siswa setelah pembelajaran diberikan. Adapun jenis tes yang digunakan adalah 15 soal pilihan ganda dengan taksonomi pertanyaan tingkat Bloom (mengingat dan memahami) [11]. Artinya, tes yang digunakan benar-benar mengukur kemampuan berpikir kreatif siswa, oleh karena itu soal-soal tersebut diujikan (trial) kepada siswa. Dari hasil tes diperoleh data yang dapat diolah untuk menciptakan umpan balik yang baik bagi guru atau siswa. Skor dari setiap jawaban yang benar menandai 1 dan 0 untuk jawaban yang salah. Soal-soal tersebut diujikan kepada kedua kelas yang mendapatkan pemanfaatan teknologi audio visual dengan menggunakan metode resitasi pada mata pelajaran PKn di MTs Thoriqulhuda, Dano (kelas eksperimen) dan kelas yang mendapatkan mata pelajaran PKn menggunakan metode resitasi tanpa media audio visual (kelas kontrol). Kemudian setelah lembar jawaban siswa diberi tanda dan data dianalisis untuk menguji apakah ada perbedaan antara kelas eksperimen dan kelas kontrol terlebih dahulu, dengan menggunakan metode pengujian Lilliefors untuk mengetahui normalitas dengan bantuan software SPSS versi (Statistical Product and Service Solutions) versi 20.00 dengan kriteria pengujian. [12]

Lmaks $<\mathrm{L}$ tabel: data terdistribusi normal

Lmaks> L tabel: data terdistribusi tidak normal

Perhitungan tes Lillefors di kelas eksperimen dan di kelas kontrol adalah sebagai berikut:

TABEL II.

Kelas Eksperimen Pre-Test Dan Kelas Kontrol Normalitas Tes Normalitas

Tests of Normality

\begin{tabular}{|c|l|l|l|l|l|l|l|}
\hline \multirow{2}{*}{} & Learning & \multicolumn{3}{|l|}{$\begin{array}{l}\text { Kolmogorov- } \\
\text { Smirnov }\end{array}$} & \multicolumn{3}{l|}{ Shapiro-Wilk } \\
\cline { 2 - 7 } & $\begin{array}{l}\text { Statis } \\
\text { tic }\end{array}$ & df & Sig. & $\begin{array}{l}\text { Statis } \\
\text { tic }\end{array}$ & Df & Sig. \\
\hline \multirow{2}{*}{ Score } & $\begin{array}{l}\text { multi media } \\
\text { without } \\
\text { media }\end{array}$ & .155 & 34 & .037 & .939 & 34 & .059 \\
& & .176 & 34 & .009 & .932 & 34 & .035 \\
\hline
\end{tabular}

Lilliefors Significance Correction

Dari tabel di atas diperoleh nilai data sig untuk kelas eksperimen $=0.059$, kriteria kurva normalitas adalah: 1) jika Lmaks <Ltabel maka data berdistribusi normal atau 2) jika nilai sig $>\alpha$ maka berdistribusi tidak normal. Karena nilai sig untuk kelas eksperimen lebih besar 0,059 dari nilai $\alpha$ yaitu 0,01 maka sebaran data kelas eksperimen berdistribusi normal, sedangkan untuk kelas kontrol dari tabel di atas menunjukkan bahwa nilai sig lebih besar 0,035 dari nilai $\alpha$ yaitu 0,01 maka sebaran data kelas kontrol berdistribusi normal, maka dari kedua pernyataan tersebut dapat 
disimpulkan bahwa distribusi kedua kelas berdistribusi normal.

Karena dari kedua data tersebut yaitu data kelas eksperimen dan kelas kontrol berdistribusi normal maka perlu dilakukan uji homogenitas dengan rumus hipotesis nol dan hipotesis alternatif adalah:

Rumus hipotesis yang diuji peneliti adalah sebagai berikut: Uji homogenitas kelas eksperimen dan kelas kontrol ditunjukkan pada tabel di bawah ini:

TABEL III

Uji Homogenitas Kelas Eksperimen Dan Kontrol

\begin{tabular}{|l|l|l|l|}
\hline Group & $\begin{array}{l}\text { Number of } \\
\text { Data }\end{array}$ & Average & $\begin{array}{l}\text { Standard } \\
\text { Deviation }\end{array}$ \\
\hline Experiment & 34 & 7.20 & 1.82 \\
\hline Kontrol & 34 & 8 & 1.61 \\
\hline
\end{tabular}

Dari data diatas diperoleh $\mathrm{F}$ hitung $=1,262$ dan $\mathrm{F}$ tabel $=$ 2,313 , dengan kriteria pengujian jika $\mathrm{F}$ hitung $<\mathrm{F}$ tabel maka varian homogen, karena data pre-test berdistribusi normal dan memiliki varian homogen, kemudian dilanjutkan ke uji $\mathrm{T}$.

TABEL IV.

Tes Perbandingan Hasil Belajar Kelas Eksperimen Dan Kelas Kontrol Sebelum Menggunakan Media.

Paired Samples Statistics

\begin{tabular}{|l|l|l|l|l|}
\hline & Mean & $\mathrm{N}$ & Std. Deviation & $\begin{array}{l}\text { Std. Error } \\
\text { Mean }\end{array}$ \\
\hline $\begin{array}{l}\text { Kls_ek } \\
\text { Pair 1 } \\
\begin{array}{l}\text { Kls_ctr } \\
1\end{array}\end{array}$ & 7.21 & 34 & 1.822 & .312 \\
\hline
\end{tabular}

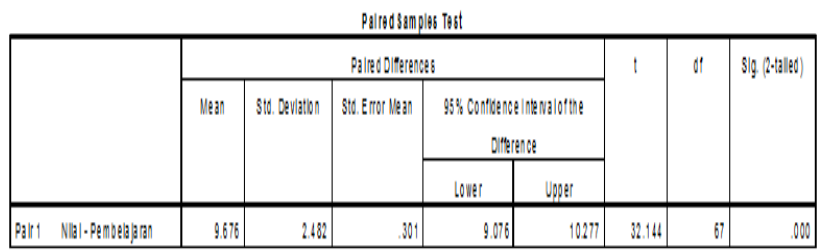

Gambar 1. Independent Samples Test

Dari hasil pengujian, dari keluaran pertama terlihat bahwa jumlah data kelas eksperimen adalah 3 siswa dengan rata-rata nilai pre-test $=7,21$, standar deviasi $=1,822$ dan jumlah data kelas kontrol adalah 34 dengan rata-rata nilai pre-test adalah $=8,00$, standar deviasi $=1,614$, sedangkan dari keluaran kedua diperoleh hasil pengujian menggunakan uji t diperoleh nilai thitung -2,433 dan nilai Asymp sig. (2-tailed) lebih kecil dari $\alpha$ dan jika lebih rendah positif dan atas adalah negatif atau bawah dan atas adalah negatif, maka Ho ditolak dan Ha diterima. Karena dalam pengujian ini nilai Asymp sig. (2tailed) $=0,000$ lebih kecil dari $\alpha=0,05$ dan lebih rendah negatif $-1,458$ dan di atas negatif $-0,130$, maka dari hasil pengujian di atas adalah Ho ditolak atau $\mathrm{H} 1$ adalah diterima, oleh karena itu dapat disimpulkan bahwa "terdapat perbedaan kemampuan matematika awal antara kelas eksperimen dan kelas kontrol sebelum menggunakan media.

Setelah peneliti melaksanakan pembelajaran pada kedua kelas yaitu kelas eksperimen, kelas yang menggunakan media audio visual dengan metode resitasi dan kelas kontrol yang dalam pembelajarannya hanya menggunakan pembelajaran resitasi tanpa menggunakan media audio visual, peneliti akan melakukan uji hipotesis untuk menguji hipotesis komparatif dua. sampel berpasangan.

Tes perhitungan Lillefors di kelas eksperimen dan kontrol adalah sebagai berikut:

TABEL V.

Tes Post-Test Normalitas Kelas Eksperimen Dan Kontrol Tests of Normality

\begin{tabular}{|c|c|c|c|c|c|c|c|}
\hline & \multirow[t]{2}{*}{ Learning } & \multicolumn{3}{|c|}{$\begin{array}{l}\text { Kolmogorov- } \\
\text { Smirnov }^{\mathrm{a}}\end{array}$} & \multicolumn{3}{|c|}{ Shapiro-Wilk } \\
\hline & & Statistic & df & Sig. & $\begin{array}{l}\text { Statisti } \\
\text { c }\end{array}$ & Df & Sig. \\
\hline $\begin{array}{l}\text { valu } \\
\text { e }\end{array}$ & $\begin{array}{l}\text { Audio } \\
\text { Visual } \\
\text { Without } \\
\text { Audio } \\
\text { Visual }\end{array}$ & .136 & 34 & .111 & .896 & 34 & .004 \\
\hline
\end{tabular}

Lilliefors Significance Correction

Dari tabel di atas diperoleh Lmaks untuk kelas eksperimen sebesar 0.136 dan Lmaks untuk kelas kontrol sebesar 0.143, dengan kriteria kurva normalitas sebagai berikut: 1) Jika Lmaks <L tabel maka data berdistribusi normal, atau 2) Jika nilai sig $>\alpha$ maka berdistribusi normal.

Untuk kelas eksperimen 'Lmaks $=0.136<\mathrm{L}$ tabel $=0.152$ maka sebaran data kelas eksperimen berdistribusi normal dan untuk kelas kontrol' Lmaks $=0.143<\mathrm{L}$ tabel $=0.152$ maka sebaran data pada kelas kontrol berdistribusi normal, sebaran data dari kelas eksperimen dan kelas kontrol dapat disimpulkan bahwa keduanya berdistribusi normal. Diperlukan uji homogenitas dengan rumus hipotesis nol. Uji homogenitas kelas eksperimen dan kelas kontrol ditunjukkan pada tabel di bawah ini:

TABEL VI,

Pre-Test Uji Homogenitas Kelas Eksperimen Dan Kontrol

Group Statistics
\begin{tabular}{|l|l|l|l|l|l|}
\hline & Learning & $\mathrm{N}$ & Mean & $\begin{array}{l}\text { Std. } \\
\text { Deviation }\end{array}$ & $\begin{array}{l}\text { Std. Error } \\
\text { Mean }\end{array}$ \\
\hline \multirow{2}{*}{ Nilai } & $\begin{array}{l}\text { Multimedia } \\
\text { Without } \\
\text { multimedia }\end{array}$ & 34 & 11.94 & 2.473 & .424 \\
& 34 & 10.41 & 1.760 & .302 \\
\hline
\end{tabular}

Dari tabel 4.5 di atas terlihat bahwa nilai rata-rata hasil belajar PKn pada kelas eksperimen adalah 11,94 atau 79,6\% 
dan pada kelas kontrol sebesar 10,41 atau 69,4\%. Dari data diperoleh $\mathrm{F}$ hitung $=1,262$ dan $\mathrm{F}$ tabel $=2,313$, dengan kriteria pengujian jika $\mathrm{F}$ hitung $<\mathrm{F}$ tabel maka varian homogen, karena nilai $\mathrm{F}$ hitung $=1,262<\mathrm{F}$ tabel $=2,313$, maka Ho diterima dan dapat disimpulkan bahwa kedua varian itu homogen.

Hipotesis penelitian

Peningkatan hasil belajar PKn antara siswa yang mendapatkan pembelajaran resitasi dengan multimedia interaktif dengan siswa yang mendapatkan pembelajaran resitasi tanpa media audio visual. Secara formal hipotesis statistik (Ho) hipotesis penelitian (Ha) sebagai berikut: Ho: $\mu 1=\mu 2$, Ha: $\mu 1>\mu 2$

Hipotesis statistik akan diuji dengan uji t jika kedua kelompok dari data tersebut berdistribusi normal, dan jika salah satu data kelompok berdistribusi tidak normal maka harus menggunakan uji Mann Whitney karena kedua data tersebut berdistribusi normal menggunakan uji t.

TABEL VII

Tes Komparasi Hasil Belajar Kelas Eksperimen Dan Kelas Kontrol Setelah Menggunakan Media

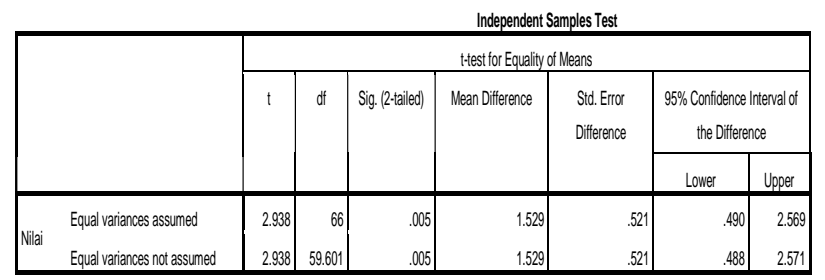

Gambar 2. Independent Samples Test

Dari tabel di atas diperoleh sig. (2-tailed) $=0,005<$ dari $\alpha$ $=0,05$ dan karena lebih rendah $=0,490$ dan atas =2,569 atau dari hasil pengujian di atas, karena lebih rendah positif dan atas positif maka Ho ditolak dan Ha diterima maka dapat disimpulkan bahwa "terdapat perbedaan peningkatan hasil belajar PKn antara siswa yang mendapatkan metode pembelajaran resitasi menggunakan media audio visual dengan siswa yang mendapatkan metode pembelajaran resitasi tanpa media audio visual.

\section{HASIL DAN PEMBAHASAN}

Hasil pengolahan data dan pengujian data menunjukkan: "Ada pengaruh model pembelajaran pengajian terhadap kegiatan pembelajaran menggunakan media audio visual terhadap peningkatan pendidikan PKn pada Kompetensi Dasar Demokrasi di MTS Thoriqulhuda, Dano Tahun Ajaran 2019/2020".

Berdasarkan pengolahan data dan pengujian data menunjukkan bahwa metode pembelajaran resitasi dan penggunaan media audio visual berpengaruh signifikan terhadap hasil belajar siswa pada mata pelajaran Pendidikan Kewarganegaraan. Hal ini dapat dilihat dari sig. (2- tailed) = $0,024<$ dari $\alpha=0,05$ dan karena lebih rendah $=0,490$ dan atas $=2,569$ atau dari hasil pengujian di atas, karena lebih rendah positif dan atas positif, Ho ditolak dan $\mathrm{Ha}$ diterima.
Selanjutnya berdasarkan nilai rata-rata kelas eksperimen dan nilai rata-rata kelas kontrol berbeda yaitu kelas eksperimen 11.94 atau $79.6 \%$ dan kelas kontrol 10.41 atau $69.4 \%$. Dengan demikian penggunaan model pembelajaran metode resitasi dan penggunaan audio visual berpengaruh signifikan terhadap peningkatan hasil belajar PKn siswa pada kompetensi dasar Demokrasi di MTS Thoriqulhuda, Dano tahun ajaran 2019/2020.

Dalam upaya ini, teknologi belajar dari pengembangan dan pengujian teori-teori tentang berbagai multimedia pembelajaran melalui penelitian ilmiah, diikuti dengan pengembangan desain lainnya, produksi, evaluasi dan pemilihan media yang telah diproduksi, serta mengembangkan penggunaannya dan akhirnya menggunakannya di lapangan. baik di tingkat kelas maupun di tingkat yang lebih tinggi.

Hal ini terlihat dari rata-rata skor kompetensi siswa kelas kontrol (hanya menggunakan metode pembelajaran resitasi) dengan nilai rata-rata 10,41 sedangkan kelas eksperimen (metode pembelajaran resitasi dengan menggunakan media audio visual) memiliki rata-rata 11,94 . Artinya siswa yang pembelajarannya menggunakan metode pembelajaran resitasi dengan media audio visual memiliki hasil belajar yang lebih tinggi dibandingkan dengan siswa yang pembelajarannya hanya menggunakan metode pembelajaran resitasi tanpa media audio visual.

Pemanfaatan teknologi dalam kehidupan manusia termasuk teknologi pembelajaran yang bertujuan untuk menyelesaikan masalah dalam pembelajaran atau mempermudah dalam membantu dalam kegiatan pembelajaran, harus mengupayakan pembelajaran yang menumbuhkan dan menekankan hasil belajar. Sedangkan teori belajar tidak hanya berbicara tentang bagaimana siswa belajar tetapi juga mempertimbangkan hal-hal lain yang mempengaruhi siswa secara psikologis, biologis, dan sosiologis. Salah satu tanda seseorang yang telah belajar adalah perubahan tingkah laku dalam dirinya.

Berdasarkan temuan penelitian ini dapat dipastikan bahwa pembelajaran merupakan peristiwa yang sangat kompleks yang dapat dipengaruhi oleh banyak faktor, baik faktor internal maupun eksternal siswa. Faktor internal seperti kecerdasan siswa, motivasi dan prestasi belajar, kebiasaan belajar, gaya belajar, merupakan beberapa faktor yang sangat berpengaruh terhadap hasil belajar siswa. Sedangkan faktor eksternal seperti lingkungan dan kesempatan yang tersedia, alat-alat yang digunakan dalam kegiatan belajar mengajar, keadaan keluarga juga akan mempengaruhi hasil belajar siswa.

\section{KESIMPULAN}

Berdasarkan hasil penelitian yang diperoleh selama melakukan kegiatan penelitian tentang penggunaan Model Pembelajaran Resitasi dengan media audio visual dalam meningkatkan hasil belajar PKn siswa pada materi demokrasi 
di MTs Thoriqulhuda, Dano tahun pelajaran 2019/2020, berikut kesimpulannya diperoleh:

1. Penggunaan model pembelajaran resitasi dengan media audio visual dapat meningkatkan hasil belajar siswa. Bahwa hasil belajar PKn siswa berbeda, dimana nilai rata-rata pembelajaran menggunakan media audio visual adalah $79,6 \%$.

2. Penggunaan model pembelajaran resitasi tanpa media audio visual tidak meningkatkan hasil belajar PKn siswa. Bahwa terdapat perbedaan hasil belajar PKn siswa, dimana nilai rata-rata pembelajaran tanpa media audio visual adalah $69,4 \%$.

3. Hasil belajar siswa yang mendapatkan pembelajaran dengan metode resitasi dan media audio visual lebih baik daripada siswa yang mendapatkan pembelajaran dengan metode resitasi tanpa media audio visual dilihat dari nilai rata-rata kelas eksperimen sebesar 11,94 dan kelas kontrol sebesar 10,41.

\section{UCAPAN TERIMA KASIH}

Terima kasih kepada seluruh pihak yang berperan memberikan kelancaran dan kemudahan dalam pengambilan informasi penelitian yang kami lakukan terutama kepada kepala sekolah MTs Thoriqulhuda Dano Kabupaten Garut.

\section{DAFTAR PUSTAKA}

[1] D. Darmawan, Teknologi Pembelajaran, 6th ed. Bandung: PT Remaja Rosdakarya Offset, 2017.

[2] P. D. Sugiyono, “済無No Title No Title,” J. Chem. Inf. Model., vol. 53, no. 9, pp. 1689-1699, 2016, doi: 10.1017/CBO9781107415324.004.

[3] T. Dwi, N. Marwinda, D. P. Matematika, and U. P. Indonesia, "Penerapan Model Pembelajaran Kooperatif Tipe Two Stay Two Stray Dengan Time Token Untuk Meningkatkan Kemampuan," vol. 1, pp. 15-19, 2020.

[4] Y. Agnesti and C. Materials, "Penerapan Pendekatan Kontekstual dalam Menyelesaikan Soal Cerita pada Materi Perbandingan dan Skala terhadap Siswa SMP Mosharafa: Jurnal Pendidikan Matematika Mosharafa : Jurnal Pendidikan Matematika," vol. 9, pp. 347-358, 2020, doi: https://doi.org/10.31980/mosharafa.v9i2.748.

[5] Umi Hanik, "Strategi dan Metode Pembelajaran," Tesis, pp. 27-70, 2008, [Online]. Available: http://eprints.walisongo.ac.id/355/4/UmiHanik_Tesis_Bab2.pdf.

[6] Herdiana, "Media Audio Visual,” J. Chem. Inf. Model., vol. 53, no. 9, pp. 1689-1699, 2013, doi: 10.1017/CBO9781107415324.004.

[7] B. A. B. Ii and A. K. Teori, “10 . 9,” vol. 2, no. 4, pp. 8-19, 2015.

[8] N. H. Waryanto, "Penggunaan Media Audio Visual dalam Menunjang Pembelajaran *)," Pendidikan, vol. 05, no. 02, pp. 1-8, 2007.

[9] Rosantiana NM, "Penerapan Media Audio Visual Untuk Meningkatkan Hasil Belajar Siswa Kelas VII Pada Pembelajaran PKn di SMP Muhammadiyah 4 Semarang.," Penerapan Media Audio Vis. Untuk Meningkat. Has. Belajar Siswa Kelas VII Pada Pembelajaran PKn di SMP Muhammadiyah 4 Semarang., vol. 1, no. 2, pp. 1-58, 2016.

[10] J. Fleming and K. E. Zegwaard, "Methodologies, methods and ethical considerations for conducting research in work-integrated learning,"
Int. J. Work. Learn., vol. 19, no. 3, pp. 205-213, 2018.

[11] R. Sundayana, Statistika Penelitian Pendidikan, Alfabeta. Bandung, 2014.

[12] R. (2014). Sundayana, Statistika Penelitian Pendidikan. Bandung: Alfabeta. 